\title{
ANALISIS DAYA DUKUNG TIANG PANCANG DENGAN METODE STATIK, DINAMIK, DAN PERSAMAAN GELOMBANG SOFTWARE GRLWEAP
}

\author{
Chris Tengdyantono ${ }^{1}$, Gregorius Sandjaja Sentosa² dan Aksan Kawanda ${ }^{3}$ \\ ${ }^{1}$ Program Studi Sarjana Teknik Sipil, Universitas Tarumanagara, Jl. Letjen S. Parman No.1 Jakarta \\ Email: christengg_3@yahoo.com \\ ${ }^{2}$ Program Studi Sarjana Teknik Sipil, Universitas Tarumanagara, Jl. Letjen S. Parman No.1 Jakarta \\ Email: gregoriuss@ft.untar.ac.id \\ ${ }^{3}$ Program Studi Sarjana Teknik Sipil, Universitas Tarumanagara, Jl. Letjen S. Parman No.1 Jakarta \\ Email: akawanda@geotech-indonesia.com
}

\begin{abstract}
ABSTRAK
Formula pemancangan tiang secara luas digunakan untuk menentukan daya dukung statis dari tiang. Dedikasi dan kecerdasan yang luar biasa telah dikeluarkan oleh para insinyur dalam pengembangan formula pemancangan tiang. Terdapat banyak sekali formula yang digunakan untuk pemancangan tiang, dan para insinyur tidak bisa menyetujui formula mana yang terbaik. Akibatnya, semua rumus pemancangan tiang bersifat empiris dan hanya berlaku untuk jenis atau panjang tertentu. Esai ini disajikan dengan tujuan memberikan insinyur konsepsi tentang metode mana meminimalkan risiko tersebut, termasuk bagaimana menerapkan GRLWEAP untuk menganalisis drivebility tanah dengan menyediakan parameter. Penggunaan formula program GRLWEAP direkomendasikan dalam perhitungan kapasitas daya dukung aksial karena memiliki tingkat akurasi mencapai rentang $\pm 5 \%$ jika dibandingkan terhadap hasil uji PDA / Pile Driving Analyzer proyek jembatan yang berlokasi di Jakarta Utara dan dapat memudahkan proses simulasi serta mengurangi resiko kegagalan konstruksi yang dapat menimbulkan dampak kerugian biaya, material, dan waktu..
\end{abstract}

Kata kunci: pemancangan tiang, kapasitas daya dukung, formula dinamik, GRLWEAP, PDA

\section{PENDAHULUAN}

\section{Latar belakang}

A.T Kearney, a leading global management consulting firm berbasis di Chicago mengidentifikasi kota-kota dan mengkategorikan kota-kota tersebut sebagai Emerging Cities Outlook (ECO). Jakarta, Manila, dan Kuala Lumpur adalah tiga kota di Asia Tenggara yang diproyeksikan sebagai kota yang berprospek di masa yang akan datang. Jakarta berada di urutan pertama ECO dengan indeks 24,7. Aspek-aspek yang dinilai dalam ECO yaitu sumber daya manusia, inovasi, aktivitas bisnis dan sektor pembangunan. Perusahaan konsultan berbasis internasional ini menggambarkan bahwa pembangunan merupakan salah satu faktor yang mempengaruhi indeks kualitas hidup, maka dari itu demi meningkatkan kualitas hidup manusia pembangunan harus tetap dikembangkan.

Fondasi merupakan salah satu bagian konstruksi bangunan yang berfungsi meneruskan beban bangunan diatasnya (termasuk beban sendiri), kepada tanah tempat fondasi tersebut berpijak, tanpa mengakibatkan terjadinya penurunan bangunan di luar batas toleransinya. Sehingga dalam perencanaan fondasi harus dilakukan dengan teliti dan secermat mungkin, setiap fondasi harus dapat memikul beban yang telah ditentukan atau bahkan beban maksimum yang mungkin terjadi. Oleh karena itu, dengan melihat komparasi dari metode yang akan disajikan melalui studi berikut, diharapkan para perencana fondasi akan dapat merencanakan daya dukung fondasi, serta menanggulangi settlement atau penurunan secara akurat, teliti, dan efektif.

\section{Identifikasi masalah}

Seringkali kita dapati terjadinya settlement atau penurunan karena diakibatkan oleh beban struktur bangunan yang melampaui batas toleransinya. Sehingga dalam perencanaan fondasi harus dilakukan dengan teliti dan secermat mungkin, setiap fondasi harus dapat memikul beban yang telah ditentukan atau bahkan beban maksimum yang mungkin terjadi. Oleh karena itu perlu dilakukan evaluasi dan komparasi dari berbagai metode guna memperoleh nilai daya dukung fondasi yang tepat secara efektif.

Perencanaan fondasi dapat dilaukan dengan melakukan perhitungan secara manual ataupun mengunakan bantuan program simulasi. Salah satu program simulasi yang dapat digunakan dalam perencanaan fondasi antara lain 
GRLWEAP. Program ini dapat digunakan untuk perencanaan fondasi di daratan maupun di lepas pantai (offshore). Dalam studi ini, program GRLWEAP akan digunakan dalam perencanaan fondasi di daratan.

\section{Tujuan penelitian}

Maksud dari penelitian ini adalah untuk mengetahui seberapa besar kapasitas daya dukung aksial tiang pancang berdasarkan formula statik, dinamik, persamaan gelombang program GRLWEAP serta mengetahui seberapa relevan komparasi kapasitas daya dukung aksial tiang pancang dari seluruh metode terhadap hasil uji PDA di lapangan.

\section{Lingkup penelitian}

Adapun lingkup pada penelitian ini, yaitu analitis kapasitas daya dukung aksial tiang pancang berdasarkan formula statik, dan formula dinamis menggunakan program Microsoft Excel, analisis kapasitas daya dukung aksial tiang pancang berdasarkan persamaan gelombang mengunakan program simulasi GRLWEAP, beban yang digunakan hanya beban aksial,dan melakukan perbandingan analisis kapasitas dengan formula statik, dinamik, GRLWEAP, dan aktual lapangan dari hasil uji PDA.

\section{DASAR TEORI}

Kapasitas aksial fondasi tiang pancang ditentukan oleh kemampuan material tiang untuk menahan beban (kapasitas struktural) atau daya dukung tanah, dengan daya dukung terkecil yang lebih menentukan. Daya dukung tanah pada fondasi tiang pancang dapat dihitung dengan cara statik, berdasarkan korelasi langsung dengan uji lapangan (in-situ test), dengan formula dinamik (dari rekaman pemancangan), analisis perambatan gelombang, berdasarkan hasil pendongkrakan secara hidrolik, dan dengan pengujian di lapangan.

\section{Penentuan daya dukung aksial fondasi tiang pancang cara statik}

Penentuan daya dukung aksial fondasi tiang pancang dengan cara statik dapat dilakukan dengan beberapa cara berikut.

\section{Daya dukung ujung tiang $\left(Q_{P}\right)$}

- Pada Tanah Pasir

$$
Q_{p 1}=A_{p} \cdot q_{p}=A_{p} \cdot q^{\prime} \cdot N_{q *}
$$

keterangan : $Q_{p 1}=$ Daya dukung ultimit ujung tiang (ton), $A_{p}=$ Luas penampang ujung tiang $\left(\mathrm{m}^{2}\right), q_{p}=q^{g} \cdot N_{q s}$ = Daya dukung per satuan luas (ton $\left./ \mathrm{m}^{2}\right), q^{J}=$ Tegangan vertical efektif (ton $\left./ \mathrm{m}^{2}\right), N_{\mathrm{q} *}=$ Faktor daya dukung ujung tiang.

- $\quad$ Pada Tanah Lempung

$$
Q_{p}=A_{p} \cdot q_{p}=A_{p} \cdot\left(C_{u} \cdot N_{c *}\right) \approx A_{p} \cdot\left(9 \cdot C_{u}\right)
$$

keterangan : $Q_{p}=$ Daya dukung ultimit ujung tiang (ton), $A_{p}=$ Luas penampang ujung tiang $\left(\mathrm{m}^{2}\right), C_{u}=$ Kohesi tak terdrainase (ton $\left./ \mathrm{m}^{2}\right), N_{c s}=$ Faktor daya dukung ujung.

\section{Daya dukung selimut tiang $(Q s)$}

$$
Q_{s}=\Sigma\left(A_{s} \cdot f_{s}\right)
$$

keterangan : $A_{s}=$ Luas selimut tiang $\left(\mathrm{m}^{2}\right)=p \times \Delta L, \Delta L=$ Panjang segmen tiang $(\mathrm{m}), f_{s}=$ Gesekan selimut satuan $\left(\right.$ ton $\left./ \mathrm{m}^{2}\right)$.

Berikut adalah beberapa metode yang dapat digunakan untuk menentukan selimut $\left(f_{s}\right)$ dari tiang.

- Pada Tanah Pasir

$$
f_{s}=K \cdot \sigma_{v}^{\prime} \cdot \tan \delta
$$


$\mathrm{K}_{\mathrm{o}}<\mathrm{K}<1.8 \mathrm{~K}_{\mathrm{o}}$

- Metode Alpha (Tomlinson)

$$
f_{s}=\alpha \cdot c_{u}
$$

keterangan : $f_{s}=$ Gesekan selimut $\left(\operatorname{ton} / \mathrm{m}^{2}\right), \alpha=$ Faktor adhesi, $C_{u}=$ Kohesi tak terdrainase (ton $\left./ \mathrm{m} 2\right)$.

- Metode Beta (Metode tegangan efektif)

$$
f_{\text {save }}=\beta \cdot \sigma_{v}^{\prime}
$$

keterangan $: f_{s \text { ave }}=$ Gesekan selimut rata - rata $\left(\operatorname{ton} / \mathrm{m}^{2}\right), \beta=K \cdot \tan \theta \mathrm{r}, \theta \mathrm{r}=$ Sudut geser terdrainase dari sampel tanah yang teremas $($ remolded $), \mathrm{K}=\left(1-\sin \theta_{r}\right) . O C R^{0.5}, \sigma_{v}^{\prime}=$ Tegangan vertikal efektif tanah.

\section{Penentuan daya dukung aksial fondasi tiang pancang cara dinamik}

1. Formula Hiley (a)

$$
R U T=\frac{e_{h} \cdot E_{h}}{s+0.5 \cdot\left(k_{1}+k_{2}+k_{3}\right)} \cdot \frac{W_{r}+n^{2} \cdot W_{p}}{W_{r}+W_{p}}
$$

keterangan $: k_{1}=$ dari tabel 1.1 (dengan memperkirakan nilai RUT), $k_{2}=\frac{R U T \cdot L}{(A \cdot E)}, k_{3}=$ Quake dari tanah.

Cara perhitungan dilakukan dengan iterasi hingga konvergen.

2. Formula Hiley (b)

$$
R U T=\frac{e_{h} \cdot E_{h}}{s+0.5 \cdot C_{x}} \cdot \frac{W_{r}+n^{2} \cdot W_{p}}{W_{r}+W_{p}}
$$

Dimana $C_{x}$ adalah pencatatan rebound dari pukulan terakhir.

3. Formula PCUBC

$$
R U T=\frac{e_{h} \cdot E_{h} \cdot C_{1}}{s+C_{2}}
$$

keterangan : $C_{1}=\frac{W_{r}+k \cdot W_{p}}{W_{r}+W_{p}}, C_{2}=\frac{R U T \cdot L}{(A \cdot E)}, k=0.25$ (untuk tiang baja), $k=0.1$ (untuk tiang lain)

Cara perhitungan dilakukan dengan iterasi hingga konvergen.

4. Formula Gates

$$
R U T=104.5 \cdot \sqrt{e_{h} \cdot E_{h} \cdot(2.4-\log s)}
$$

5. Formula Modified ENR

6. Formula Janbu

$$
R U T=\frac{e_{h} \cdot E_{h} \cdot h}{s+0.254} \cdot \frac{W_{r}+n^{2} \cdot W_{p}}{W_{r}+W_{p}}
$$

$$
\begin{gathered}
R U T=\frac{e_{h} \cdot E_{h}}{K_{u} \cdot s} \\
\text { keterangan }: K_{u}=C_{d} \cdot\left(1+\sqrt{1+\frac{\lambda}{C_{d}}}\right), C_{d}=0.75+0.15 \cdot \frac{W_{p}}{W_{r}}, \lambda=\frac{e_{h} \cdot E_{h} \cdot L}{A \cdot E \cdot s^{2}}
\end{gathered}
$$


7. Formula Danish

$$
R U T=\frac{e_{h} \cdot E_{h}}{s \cdot C_{1}}
$$

keterangan $: C_{1}=\sqrt{\frac{e_{h} \cdot E_{h} \cdot h \cdot L}{2 \cdot A \cdot E}}$

8. Formula Canadian National Building Code (CNBC)

$$
R U T=\frac{e_{h} \cdot E_{h} \cdot C_{1}}{s+C_{2} \cdot C_{3}}
$$

keterangan : $C_{1}=\frac{W_{r}+n^{2} \cdot 0.5 \cdot W_{p}}{W_{r}+W_{p}}, C_{2}=\frac{R U T}{2 A}, C_{3}=\frac{L}{E}+0.0001$

Cara perhitungan dilakukan dengan iterasi hingga konvergen.

9. Formula Eytelwein

$$
R U T=\frac{e_{h} \cdot E_{h}}{s+0.1\left(\frac{W_{P}}{W_{T}}\right)}
$$

\section{METODOLOGI PENELITIAN}

\section{Konsep penelitian}

Melakukan perhitungan daya dukung aksial fondasi tiang pancang dengan variasi formula statik, formula dinamik, dan pemodelan struktur program simulasi GRLWEAP relevan dengan output dari perangkat pengolah data hasil uji PDA proyek. Untuk mendapatkan semua parameter yang dibutuhkan, digunakan beberapa korelasi baku dengan tabel dan beberapa peraturan. Diawali dengan mengumpulkan literatur untuk melakukan analisis kapasitas daya dukung tiang pancang berupa buku-buku, jurnal, dan tutorial penggunaan simulasi program serta peraturanperaturan yang digunakan. Data yang diperoleh dari studi literatur ini akan digunakan sebagai acuan dalam perhitungan guna memperoleh kapasitas daya dukung tiang pancang. Banyak literatur membahas mengenai perhitungan daya dukung gaya lateral dan sebagainya, namun penulis akan memfokuskan penelitian mengenai daya dukung gaya aksial tiang pancang.

\section{Analisis dan pembahasan}

Analisis data dari penelitian ini dilakukan dengan cara mengkomparasikan nilai daya dukung aksial fondasi tiang pancang dengan variasi formula statik, formula dinamik, dan pemodelan struktur formulasi rambatan gelombang dengan program simulasi GRLWEAP terhadap perangkat pengolah data hasil uji PDA proyek menggunakan grafik pada Microsoft Excel.

\section{ANALISIS DAN PEMBAHASAN}

Studi kasus ini menggunakan spesifikasi sesuai dengan proyek yang berlokasi di kawasan Jakarta Utara untuk pembangunan jembatan dengan daya dukung rencana aktual sebesar 300 ton.

\section{Parameter tiang}

Spesifikasi yang digunakan sebagai data pengolahan adalah spun pile dengan diameter $600 \mathrm{~mm}$, thickness $100 \mathrm{~mm}$, cross section area $1570.8 \mathrm{~cm}^{2}$, toe area $2827 \mathrm{~cm}^{2}$, perimeter $1.885 \mathrm{~cm}$, concrete modulus $34500 \mathrm{MPa}$, dan specific weight $23.6 \mathrm{kN} / \mathrm{m}^{2}$ untuk seluruh perhitungan pile. 


\section{Parameter hammer dan parameter cushion}

Tabel 1. Hammer parameter

\begin{tabular}{|c|c|c|c|c|c|}
\hline \multicolumn{7}{|c|}{ Hammer Parameter } \\
\hline $\begin{array}{c}\text { Hammer Type } \\
\text { (id) }\end{array}$ & $\begin{array}{c}\text { RAM } \\
\text { Weight } \\
(\mathrm{kN})\end{array}$ & $\begin{array}{c}\text { Maximum } \\
\text { Stroke } \\
(\mathrm{m})\end{array}$ & $\begin{array}{c}\text { Maximum } \\
\text { Energy } \\
(\mathbf{k N . m})\end{array}$ & $\begin{array}{c}\text { Pressure } \\
(\mathbf{k P a})\end{array}$ & Efficiency \\
\hline JUWEI DD56 & 53.92 & 3.00 & 156.92 & 10000 & 0.7 \\
\hline JUWEI DD63 & 63.73 & 3.00 & 189.274 & 10000 & 0.5 \\
\hline JUWEI DD65 & 63.73 & 2.97 & 189.274 & 10000 & 0.7 \\
\hline PILECO D46-32 & 45.12 & 3.23 & 145.75 & 9825 & 0.8 \\
\hline
\end{tabular}

Tabel 2. Pile Parameter

\begin{tabular}{|c|c|c|c|c|c|c|}
\hline \multicolumn{7}{|c|}{ Pile Parameter } \\
\hline \multirow{2}{*}{$\begin{array}{c}\text { Diameter } \\
(\mathbf{m m})\end{array}$} & \multirow{2}{*}{$\begin{array}{c}\text { Thickness } \\
(\mathrm{mm})\end{array}$} & $\begin{array}{c}\text { Pross Area Area }\left(\mathbf{c m}^{2}\right) \\
\text { Section }\end{array}$ & $\begin{array}{c}\text { Toe } \\
\text { Area }\end{array}$ & $\begin{array}{c}\text { Perimeter } \\
(\mathbf{c m})\end{array}$ & $\begin{array}{c}\text { Concrete } \\
\text { Modulus } \\
(\mathbf{M P a})\end{array}$ & $\begin{array}{c}\text { Spesific } \\
\text { Weight } \\
\left(\mathbf{k N} / \mathbf{m}^{2}\right)\end{array}$ \\
\cline { 3 - 7 } & 100 & 15708 & 2827 & 1.885 & 34500 & 25 \\
\hline
\end{tabular}

Tabel 3. Hammer cushion parameter

\begin{tabular}{|c|c|c|c|c|c|}
\hline \multicolumn{7}{|c|}{ Manufacturer's Recommended Driving System } \\
\hline Hammer Type & Area & Thickness & Helmet & Modulus & Coefficient \\
(id) & $\left(\mathbf{c m}^{2}\right)$ & $(\mathrm{mm})$ & Weight & Elasticity & of \\
& & $(\mathrm{kN})$ & (MPa) & Restitution \\
\hline \multicolumn{7}{|c|}{ JUWEI hammer didn't use any hammer cushion } \\
\hline PILECO D46-32 & 2677.41 & 88.9 & 29.358 & 3240.5 & 0.8 \\
\hline
\end{tabular}

\section{Parameter tanah}

Referensi jenis tanah yang digunakan sebagai data pengolahan merupakan data tanah proyek konstruksi jembatan di kawasan Jakarta Utara, didasari oleh hasil penelitian dari PT. Wijaya Karya Laboratorium Jasa Konstruksi. Data Penelitian yang diperoleh dalam bentuk drilling log, layout, pile driving record, settlement diagram of driving, dan summary soil investigation beberapa titik pile dari proyek konstruksi tersebut.

Tabel 4. Soil data references by PT. Wika Laboratorium

\begin{tabular}{|c|c|c|c|}
\hline \multicolumn{5}{|c|}{ Bored Hole A1-A48 } \\
\hline Layer & Depth $(\mathrm{m})$ & N-SPT & Soil Classification \\
\hline 1 & $0-12$ & 2 & Very Soft Clay \\
\hline 2 & $12-14$ & 60 & Very Dense Sand \\
\hline 3 & $14-15$ & 6 & Loose Sand \\
\hline 4 & $15-27$ & 15.8 & Stiff Clay \\
\hline 5 & $27-29$ & 5 & Loose Sand \\
\hline 6 & $29-32$ & 26 & Very Stiff Clay \\
\hline 7 & $32-37$ & 42.7 & Dense Sand \\
\hline 8 & $37-39$ & 24 & Medium Sand \\
\hline 9 & $39-44$ & 22.7 & Very Stiff Clay \\
\hline 10 & $44-48$ & 17 & Medium Sand \\
\hline 11 & $48-50$ & 30 & Very Stiff Clay \\
\hline 12 & $50-52$ & 41 & Dense Sand \\
\hline 13 & $52-56$ & 27.3 & Very Stiff Clay \\
\hline
\end{tabular}




\section{Analisis daya dukung aksial fondasi tiang pancang dengan cara statik}

Perhitungan yang dilakukan berdasarkan data proyek pembangunan yang ditinjau yaitu pada titik pile A1-A48, dan P3-D43. Berikut merupakan contoh perhitungan formula statik Meyerhof (1976) pada kedalaman 31.5 m pile A1A48:

Jenis lapisan tanah merupakan lanau (MH)

$\mathrm{N}=38.75$

$\mathrm{N}_{\mathrm{K}}=15+0.5 \cdot(N-15)$ untuk $\mathrm{N}>15=15+0.5 \cdot(38.75-15)=26.87$

$\emptyset \quad=37.5^{\circ}$

$N_{q s}=200$

Diperoleh berdasarkan pembacaan gambar faktor daya dukung ujung $N_{c \varepsilon}$ dan $N_{q *}$ (Meyerhof, 1976).

$$
\begin{aligned}
& \sigma_{v}^{\prime}=19.24 \\
& Q_{s}=\left(A_{s} \cdot f_{s}\right)=(1.884 \mathrm{~m} \cdot 1 \mathrm{~m}) \cdot(2 \times 26.875)=101.265 \mathrm{kN} \text { pada kedalaman } 31.5 \mathrm{~m} \\
& Q_{s} \mathrm{k}=1742.04 \mathrm{kN}+101.265 \mathrm{kN}=1843.31 \mathrm{kN}=184.31 \mathrm{ton} \\
& Q_{p} \quad=A_{p} \cdot q^{g} \cdot N_{q *}=0.2826 \mathrm{~m}^{2} \cdot 19.2465 \text { ton } / \mathrm{m}^{2} \cdot 200 \text { ton } / \mathrm{m}^{2}=108.7812 \text { ton } \\
& Q_{\text {Ult }}=Q_{p}+Q_{s \mathrm{k}}=108.781 \text { ton }+184.31 \text { ton }=293.112 \mathrm{ton}
\end{aligned}
$$

Jadi, nilai kapasitas daya dukung ultimate tiang pancang A1-A48 menurut formula statik Meyerhof (1976) sebesar 293.112 ton dengan skin friction sebesar 184.31 ton dan end bearing sebesar 108.781 ton pada kedalaman $31.5 \mathrm{~m}$.

\section{Analisis daya dukung aksial fondasi tiang pancang dengan cara dinamik}

Perhitungan yang dilakukan berdasarkan data proyek pembangunan yang ditinjau yaitu pada titik pile A1-A48, A1A91, P1-B37, P1-B43, P1-B76, P1-B80, P3-D43, dan P3-D86. Contoh perhitungan kapasitas daya dukung aksial diolah menggunakan data pile A1-A48 sebagai acuan dengan beberapa variasi metode dinamik antara lain:

1. Formula Hiley (a)

$k_{1}=0.0009 \mathrm{~m}$

Diperoleh berdasarkan pembacaan tabel 2.4, tegangan pemancangan RUT/A pada kepala tiang pancang yang penulis asumsikan sebesar $1050 \mathrm{ton} / \mathrm{m}^{2}$ dan tiang pancang beton pracetak dengan topi setebal $7.5-10 \mathrm{~cm}$.

$k_{2}=\frac{R U T \cdot L}{(A . E)}=\frac{1050 \text { ton } \cdot 31.5 \mathrm{~m}}{\left(0.15708 \mathrm{~m}^{2} \cdot 3538000 \text { ton } / \mathrm{m}^{2}\right)}=0.059514 \mathrm{~m}$
$k_{3}=0.0035 \mathrm{~m}$

$\frac{0.85 \cdot 12.488^{\text {ton }} / m}{0.004 m+0.5 \cdot(0.0009 m+0.059514 m+0.00035 m)} \cdot \frac{5.6 \text { ton }+0.4^{2} \cdot 11.89 \text { ton }}{5.6 \text { ton }+11.89 \text { ton }}$

$\mathrm{RUT}_{1}=126.6297$ ton $($ Iterasi ke-1)

$\mathrm{RUT}_{21}=306.096$ ton $($ Iterasi ke-21)

$\mathrm{RUT}_{22}=306.104$ ton (Iterasi ke-22)

Jadi, nilai kapasitas daya dukung ultimate tiang pancang A1-A48 menurut formula Hiley (a) sebesar 306.104 ton.

2. Formula Hiley (b)

$c_{x}=0.02 \mathrm{~m}$ 


$$
\begin{aligned}
\text { RUT } & =\frac{e_{h} \cdot E_{h}}{s+0.5 \cdot C_{x}} \cdot \frac{W_{r}+n^{2} \cdot W_{p}}{W_{r}+W_{p}}=\frac{0.85 \cdot 12.488^{\text {ton }} / m}{0.004 m+0.5 \cdot 0.02 m} \cdot \frac{5.6 \text { ton }+0.4^{2} \cdot 11.89 \text { ton }}{5.6 \text { ton }+11.89 \text { ton }} \\
& =325.232 \text { ton }
\end{aligned}
$$

Jadi, nilai kapasitas daya dukung ultimate tiang pancang A1-A48 menurut formula Hiley (b) sebesar 325.232 ton.

3. Formula PCUBC

$k=0.1$, Diperoleh berdasarkan spesifikasi tiang yang digunakan yaitu tiang beton.

$C_{1}=\frac{W_{r}+k \cdot W_{p}}{W_{r}+W_{p}}=\frac{5.6 \text { ton }+0.1^{2} \cdot 11.89 \text { ton }}{5.6 \text { ton }+11.89 \text { ton }}=0.388163$

RUT sebesar 300 ton untuk perhitungan $C_{2}$ pada iterasi awal.

$C_{2}=\frac{\text { RUT } . L}{(A \cdot E)}=\frac{300 \text { ton } .31 .5 \mathrm{~m}}{\left(0.15708 \mathrm{~m}^{2} \cdot 3538000^{\text {ton }} / \mathrm{m}^{2}\right)}=0.017004 \mathrm{~m}$

$\mathrm{RUT}_{1}=\frac{e_{h} \cdot E_{h} \cdot C_{1}}{s+C_{2}}=\frac{0.85 \cdot 12.488^{\text {ton }} / \mathrm{m} \cdot 0.388163}{0.004 \mathrm{~m}+0.017004 \mathrm{~m}}=196.1654$ ton ( Iterasi ke-1)

$\mathrm{RUT}_{20}=236.937$ ton ( Iterasi ke-20 )

RUT $_{21}=236.394$ ton ( Iterasi ke-21 $)$

Jadi, nilai kapasitas daya dukung ultimate tiang pancang A1-A48 menurut formula Pasific Coast Uniform Building Code (PCUBC) sebesar 236.394 ton.

4. Formula Gates

RUT $=104.5 \cdot \sqrt{0.85 \cdot 124.88 \mathrm{kN} / \mathrm{m} \cdot(2.4-\log 4)}=1443.64 \mathrm{kN}=144.364$ ton

Jadi, nilai kapasitas daya dukung ultimate tiang pancang A1-A48 menurut formula Gates sebesar 144.364 ton.

5. Formula Modified ENR

RUT $=\frac{0.85 \cdot 1.2488^{\text {ton }} / m \cdot 0.223 m}{0.4 m+0.254 m} \cdot \frac{0.56 \text { ton }+0.4^{2} \cdot 0.01189 \text { ton }}{0.56 \text { ton }+0.01189 \text { ton }}=355.621$ ton

Jadi, nilai kapasitas daya dukung ultimate tiang pancang A1-A48 menurut formula Modified ENR sebesar 355.621 ton.

6. Formula Janbu

$$
\begin{aligned}
& C_{d}=0.75+0.15 \cdot \frac{W_{p}}{W_{r}}=0.75+0.15 \cdot \frac{11.89 \text { ton }}{5.6 \text { ton }}=1.068485 \\
& \lambda \quad=\frac{e_{h} \cdot E_{h} \cdot L}{A \cdot E \cdot s^{2}}=\frac{0.85 \cdot 12.488^{\text {ton }} / \mathrm{m} \cdot 31.5 \mathrm{~m}}{0.15708 \mathrm{~m}^{2} \cdot 3538000^{\text {ton }} / \mathrm{m}^{2} \cdot 0.004^{2}}=37.6031 \\
& K_{u} \quad=C_{d} \cdot\left(1+\sqrt{1+\frac{\lambda}{c_{d}}}\right)=1.068485 \cdot\left(1+\sqrt{1+\frac{37.6031}{1.068485}}\right)=7.496548
\end{aligned}
$$




$$
\text { RUT }=\frac{e_{h} \cdot E_{h}}{K_{u} \cdot s}=\frac{0.85 \cdot 12.488^{\text {ton }} / \mathrm{m}}{7.496548 \cdot 0.004 \mathrm{~m}}=353.990 \text { ton }
$$

Jadi, nilai kapasitas daya dukung ultimate tiang pancang A1-A48 menurut formula Janbu sebesar 353.990 ton.

7. Formula Danish

$$
\begin{aligned}
& C_{1}=\sqrt{\frac{e_{h \cdot E_{h} \cdot h \cdot L}}{2 \cdot A \cdot E}}=\sqrt{\frac{0.85 \cdot 12.488^{\text {ton }} / \mathrm{m} \cdot 2.23 \mathrm{~m} \cdot 31.5 \mathrm{~m}}{2 \cdot 0.15708 \mathrm{~m}^{2} \cdot 3538000^{\text {ton }} / \mathrm{m}^{2}}}=0.025901 \\
& \text { RUT }=\frac{e_{h} \cdot E_{h}}{s \cdot C_{1}}=\frac{0.85 \cdot 12.488^{\text {ton }} / \mathrm{m}}{0.004 \mathrm{~m} \cdot 0.025901}=355.003 \mathrm{ton}
\end{aligned}
$$

Jadi, nilai kapasitas daya dukung ultimate tiang pancang A1-A48 menurut formula Danish sebesar 355.003 ton.

8. Formula Canadian National Building Code (CNBC)

$$
C_{1}=\frac{W_{r}+n^{2} \cdot 0.5 \cdot W_{p}}{W_{r}+W_{p}}=\frac{5.6 \text { ton }+0.4^{2} \cdot 0.5 \cdot 11.89 \text { ton }}{5.6 \text { ton }+11.89 \text { ton }}=0.374567
$$

RUT sebesar 100 ton untuk perhitungan $C_{2}$ pada iterasi awal.

$$
\begin{aligned}
& C_{2}=\frac{R U T}{2 A}=\frac{100 \text { ton }}{2 \cdot 0.15708 \mathrm{~m}^{2}}=318.3091 \\
& C_{3}=\frac{L}{E}+0.0001=\frac{31.5 \mathrm{~m}}{3538000^{\text {ton }} / \mathrm{m}^{2}}+0.0001=0.000109 \\
& \text { RUT }_{1}=\frac{e_{h} \cdot E_{h} \cdot C_{1}}{s+C_{2} \cdot C_{3}}=\frac{0.85 \cdot 12.488^{\text {ton }} / \mathrm{m} \cdot 0.374567}{0.004 m+318.3091 \cdot 0.000109}=102.831 \text { ton ( Iterasi ke-1) } \\
& \text { RUT }_{40}=101.5003 \text { ton ( Iterasi ke-40) } \\
& \text { RUT }_{41}=101.466 \text { ton ( Iterasi ke-41) }
\end{aligned}
$$

Jadi, nilai kapasitas daya dukung ultimate tiang pancang A1-A48 menurut formula Canadian National Building Code (CNBC) sebesar 101.466 ton.

9. Formula Eytelwein

$$
\text { RUT }=\frac{e_{h} \cdot E_{h}}{s+0.1\left(\frac{W_{P}}{W_{r}}\right)}=\frac{0.85 .12 .488^{\text {ton }} / \mathrm{m}}{0.004 m+0.1 \cdot \frac{11.89 \text { ton }}{5.6 \text { ton }}}=49.069 \text { ton }
$$

Jadi, nilai kapasitas daya dukung ultimate tiang pancang A1-A48 menurut formula Eytelwein sebesar 49.069 ton.

\section{Analisis daya dukung aksial fondasi tiang pancang dengan program GRLWEAP}

Spesifikasi tiang yang digunakan sebagai data pengolahan adalah spun pile dengan diameter $600 \mathrm{~mm}$, thickness 100 $\mathrm{mm}$, cross section area $1570.8 \mathrm{~cm} 2$, toe area $2827 \mathrm{~cm} 2$, perimeter $1.885 \mathrm{~cm}$, concrete modulus $34500 \mathrm{MPa}$, dan specific weight $23.6 \mathrm{kN} / \mathrm{m} 2$ untuk seluruh perhitungan pile. 


\begin{tabular}{|c|c|c|c|c|}
\hline \multicolumn{4}{|l|}{ Pile Information- } & \multirow[b]{2}{*}{ Segments } \\
\hline Length & 55. & $\mathrm{~m}$ & Auto & \\
\hline Penetration & 54. & $\mathrm{~m}$ & Auto. & S-Length \\
\hline Section Area & 1570.79 & $\mathrm{~cm}^{\wedge} 2$ & Auto. & S-St, Wt \\
\hline Elast Modulus & 34500. & $\mathrm{MPa}$ & & \\
\hline Spec Weight & 23.6 & $\mathrm{kN} / \mathrm{m}^{\wedge}$ & 3 & \\
\hline Toe Area & 2827.43 & $\mathrm{~cm}^{\wedge} 2$ & 0 & Splices \\
\hline Perimeter & 1.885 & $\mathrm{~m}$ & Pile Typ & \\
\hline Pile Size & 600. & $\mathrm{~mm}$ & Unknow & \\
\hline
\end{tabular}

Gambar 1. Tampilan pile information

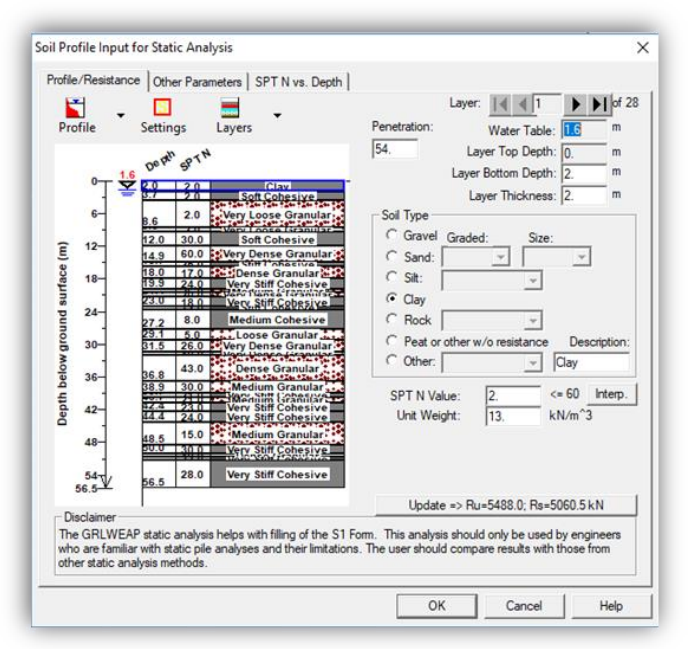

Gambar 3. Tampilan soil profile input
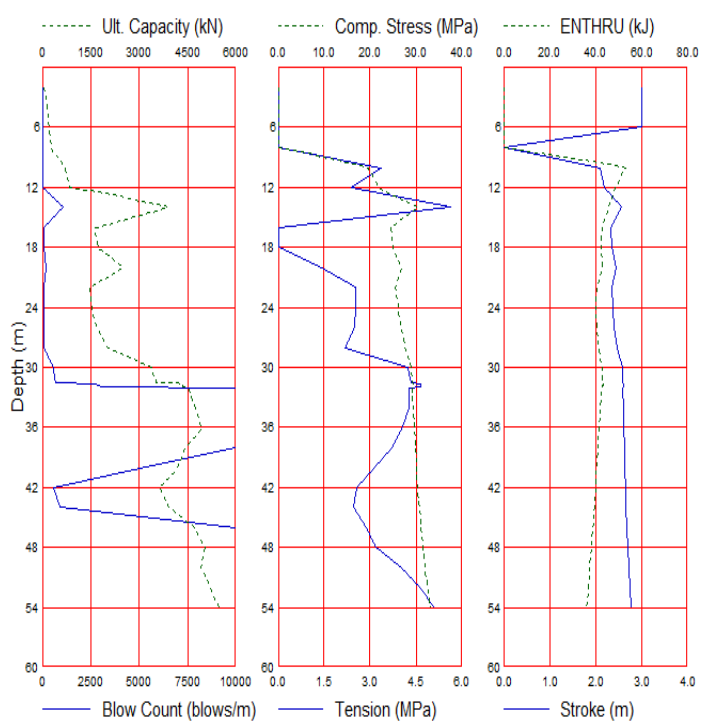

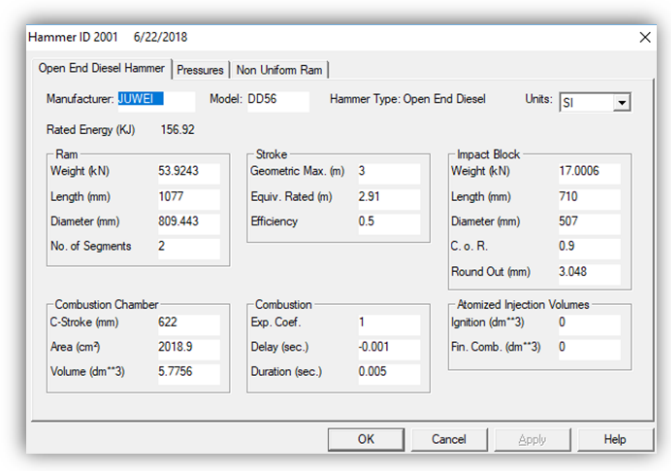

Gambar 2. Tampilan JUWEI DD56 hammer's information

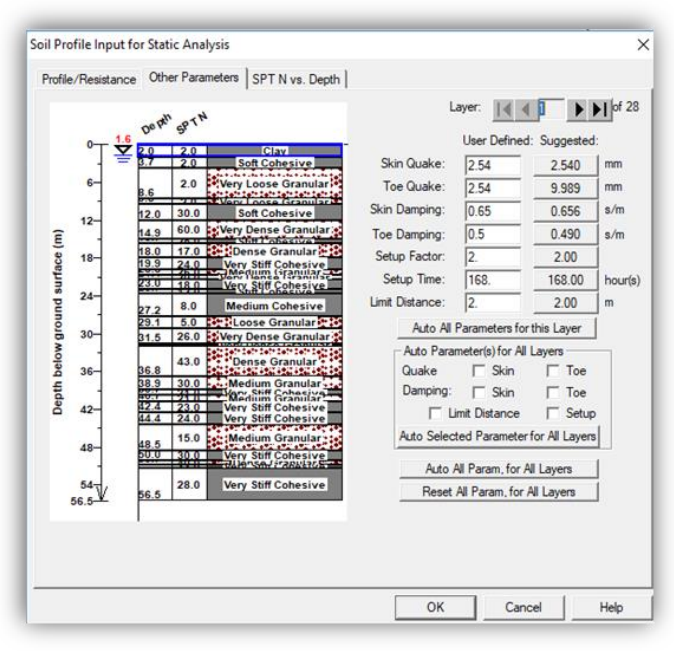

Gambar 4. Tampilan other parameters soil profile

Gambar 5. Hasil output perhitungan analisis hammer JUWEI DD56

Gambar 5 menunjukkan bahwa pada kedalaman $30 \mathrm{~m}$, terjadi peningkatan pada nilai ultimate capacity sebesar $3389.6 \mathrm{kN}$ (1919.4 kN friction dan $1470.3 \mathrm{kN}$ end bearing) jika dibandingkan terhadap nilai ultimate capacity pada kedalaman $28 \mathrm{~m}$ sebesar $2030 \mathrm{kN}(1747.3 \mathrm{kN}$ friction dan $282.7 \mathrm{kN}$ end bearing). Pada kedalaman $30 \mathrm{~m}$, pile berpijak pada tanah keras dikarenakan sudah tercapainya nilai kapasitas rencana sebesar $3000 \mathrm{KN}$ dan ultimate capacity terus mengalami peningkatan. 
Tabel 5. Hasil perhitungan daya dukung aksial terhadap hasil uji PDA

\begin{tabular}{|l|l|l|l|l|l|l|l|}
\hline A1 - A48 & A1 - A91 & P1 - B37 & P1 - B43 & P1 - B76 & P1 - B80 & P3 - D43 & P3 - D86 \\
\hline
\end{tabular}

\begin{tabular}{|c|c|c|c|c|c|c|c|c|}
\hline Hiley A & 306.104 & 305.305 & 301.204 & 301.525 & 298.608 & 314.140 & 356.976 & 266.872 \\
\hline Hiley B & 325.232 & 317.901 & 266.901 & 266.340 & 264.624 & 286.908 & 381.922 & 233.566 \\
\hline Gates & 144.364 & 141.751 & 141.496 & 141.338 & 141.338 & 147.169 & 164.680 & 127.560 \\
\hline Modified ENR & 355.621 & 330.746 & 287.524 & 290.847 & 290.775 & 341.810 & 519.413 & 187.123 \\
\hline Janbu & 353.990 & 353.148 & 345.129 & 345.890 & 342.831 & 359.306 & 403.750 & 308.236 \\
\hline Danish & 355.003 & 358.185 & 361.602 & 366.319 & 363.931 & 368.021 & 378.419 & 359.305 \\
\hline CNBC & 101.466 & 100.571 & 102.526 & 101.529 & 101.044 & 105.376 & 118.131 & 91.967 \\
\hline Eytelwein & 49.069 & 48.830 & 52.684 & 51.199 & 50.439 & 54.687 & 68.568 & 43.000 \\
\hline PCUBC & 236.394 & 237.027 & 233.837 & 233.296 & 230.738 & 241.466 & 270.261 & 209.555 \\
\hline Meyerhof 1976 & 293.11 & - & - & - & - & - & 244.95 & - \\
\hline GRLWEAP & 352.71 & - & - & - & - & - & 366.65 & - \\
\hline PDA & 350.1 & 310.3 & 317.1 & 401.1 & 228.2 & 314.9 & 368.3 & 402.3 \\
\hline
\end{tabular}

Tabel 6. Persentase selisih hasil perhitungan daya dukung aksial terhadap hasil uji PDA

\begin{tabular}{|c|c|c|c|c|c|c|c|c|}
\cline { 2 - 9 } PERSENTASE $(\%)$ & A1 - A48 & A1 - A91 & P1 - B 37 & P1 - B43 & P1 - B76 & P1 - B80 & P3 - D43 & P3 - D86 \\
\hline Hiley A & -12.57 & -1.61 & -5.01 & -24.83 & 30.85 & -0.24 & -3.07 & -33.66 \\
\hline Hiley B & -7.10 & 2.45 & -15.83 & -33.60 & 15.96 & -8.89 & 3.70 & -41.94 \\
\hline Gates & -58.76 & -54.32 & -55.38 & -64.76 & -38.06 & -53.26 & -55.29 & -68.29 \\
\hline Modified ENR & 1.58 & 6.59 & -9.33 & -27.49 & 27.42 & 8.55 & 41.03 & -53.49 \\
\hline Janbu & 1.11 & 13.81 & 8.84 & -13.76 & 50.23 & 14.10 & 9.63 & -23.38 \\
\hline Danish & 1.40 & 15.43 & 14.03 & -8.67 & 59.48 & 16.87 & 2.75 & -10.69 \\
\hline CNBC & -71.02 & -67.59 & -67.67 & -74.69 & -55.72 & -66.54 & -67.93 & -77.14 \\
\hline Eytelwein & -85.98 & -84.26 & -83.39 & -87.24 & -77.90 & -82.63 & -81.38 & -89.31 \\
\hline PCUBC & -32.48 & -23.61 & -26.26 & -41.84 & 1.11 & -23.32 & -26.62 & -47.91 \\
\hline Meyerhof 1976 & -16.28 & - & - & - & - & - & -33.49 & - \\
\hline GRLWEAP & 0.75 & - & - & - & - & - & -0.45 & - \\
\hline
\end{tabular}

$\square=$ Berada di dalam rentang $\pm 5 \%$ dari PDA

\section{KESIMPULAN}

Berdasarkan hasil analisis yang telah dilakukan, dapat diambil beberapa kesimpulan sebagai berikut:

1. Tabel 6 menyatakan bahwa persentase selisih hasil perhitungan daya dukung aksial fondasi tiang pancang bervariasi dan memiliki konsistensi yang berbeda - beda pada setiap perhitungan titik pile. Hasil daya dukung aksial program simulasi GRLWEAP merupakan hasil yang paling relevan terhadap hasil uji PDA dengan persentase kesalahan $0.75 \%$ pada titik pile A1-A48 dan 0,45\% pada titik pile $\mathrm{P} 3-\mathrm{D} 43$.

2. Penggunaan formula program GRLWEAP direkomendasikan dalam perhitungan kapasitas daya dukung aksial karena memiliki tingkat akurasi mencapai rentang $\pm 5 \%$ jika dibandingkan terhadap hasil uji PDA / Pile Driving Analyzer proyek jembatan yang berlokasi di Jakarta Utara ini.

3. Hasil perhitungan kapasitas daya dukung aksial yang diperoleh dari beberapa metode empiris berbeda - beda dikarenakan adanya perbedaan parameter yang digunakan dalam perhitungan masing - masing metode, banyaknya asumsi, korelasi baku dan penyerdehanaan.

4. Penggunaan program simulasi GRLWEAP dapat memudahkan proses simulasi serta mengurangi resiko kegagalan konstruksi yang dapat menimbulkan dampak kerugian biaya, material, dan waktu. Dapat dilihat berdasarkan nilai compression stress dan tension stress yang diperoleh berdasarkan perhitungan.

\section{DAFTAR PUSTAKA}

Bowles, Joseph E. 1989. Sifat-Sifat Fisis dan Geoteknis Tanah. Jakarta: Penerbit Erlangga.

Coduto, D.P., William A. Kitch dan Man-chu Ronald Yeung. 1994. Foundation Design Principles and Practices. London: Pearson Education Ltd.

Coduto, D.P., William A. Kitch dan Man-chu Ronald Yeung. 2001. Foundation Design Principles and Practices Second Edition. London: Pearson Education Ltd.

Das, Braja M. 2007. Principles of Foundation Engineering Sixth Edition. Canada: Thomson Canada Limited.

Das, Braja M. 2011. Geotechnical Engineering Handbook. USA: J.Ross Publishing, Inc.

Goble Rausche Likins and Associates, Inc. 2005. GRLWEAP ${ }^{T M}$ Wave Equation Analysis of Pile Driving: Procedures and Models Version 2005. USA: Pile Dynamics, Inc.

Hardiyatmo, Hary Christady. 2008. Teknik Pondasi 2. Jakarta: Gramedia Pustaka Utama.

Hardiyatmo, Hary Christady. 2011. Analisis dan Perancangan Fondasi I. Edisi Kedua. Yogyakarta: Gadjah Mada University Press.

Rahardjo, P.P., 2005. Manual Pondasi Tiang. Edisi Ketiga. Bandung: Geotechnical Engineering Center.

Sandjaja, Gregorius. 2015. Diktat Pondasi Tiang II. Jakarta: Universitas Tarumanagara.

Terzaghi, Karl dan Ralph B. Peck. 1987. Mekanika Tanah dalam Praktek Rekayasa Jilid 1. Edisi Kedua. Jakarta: Penerbit Erlangga.

Terzaghi, Karl dan Ralph B. Peck. 1991. Mekanika Tanah dalam Praktek Rekayasa Jilid -2. Edisi Kedua. Jakarta: Penerbit Erlangga.

Tomlinson, M.J., 2001, Foundation Design and Construction Seventh Edition, USA: Addison-Wesley Longman Ltd.

Tomlinson, M.J., 2008, Pile Design and Construction Practice Fifth Edition, USA: Taylor \& Francis. 